\title{
ANALISIS FAKTOR-FAKTOR YANG MEMENGARUHI INTERNET BASED CORPORATE GOVERNANCE DISCLOSURE PADA PERUSAHAAN SEKTOR PERBANKAN YANG TERDAFTAR DI BURSA EFEK INDONESIA
}

\author{
Jalasena Putra Hardianto, Ihyaul Ulum, \\ A. Syaiful Hidayat Anwar \\ Program Studi Akuntansi Fakultas Ekonomi dan Bisnis \\ Universitas Muhammadiyah Malang. \\ Jl. Raya Tlogomas No. 246 Malang \\ Email: Senaputra20@gmail.com
}

\begin{abstract}
$A B S T R A C T$
This study aims to knowing the determinants of internet based corporate governance disclosure by Indonesian Banking Companies Listed. Internet based corporate governance disclosure used an dependent variable and measured using 22 aspect that disclosure on official website. Size of Companies, Age of Companies Listed, and Dispertion Ownership used an independent variable. Size of Company measured using Log of Total Asset. Age Of companies Listed measured using difference of date companies listed minus date of research. Dispertion ownership measured using ownership of stock e"5\%. Analysis techniques data using WarpPLS 3.0. This study found Size of Companies positively and significantly effect to IBCGD. Age of Companies Listed and Dispertion Ownership haven't effect to IBCGD.
\end{abstract}

Keywords: Internet Based Corporate Governance Disclosure (IBCGD), Size of Companies, Age of Companies Listed, Dispertion Ownership

\section{PENDAHULUAN}

Selama sepuluh tahun terakhir ini, istilah Good Corporate Governance (GCG) kian populer. Tak hanya populer, istilah tersebut juga ditempatkan di posisi terhormat. Pertama, GCG merupakan salah satu kunci sukses perusahaan untuk tumbuh dan menguntungkan dalam jangka panjang, sekaligus memenangkan persaingan bisnis global. Kedua, krisis ekonomi di kawasan Asia dan Amerika Latin yang diyakini muncul karena kegagalan penerapan GCG (Daniri, 2005).

Perusahaan memilih media internet sebagai sarana pengungkapan (disclosure) karena semua orang memiliki akses yang baik dan juga salah satu tujuan perusahaan mengungkapkan hal-hal tertentu adalah sebagai wujud akuntabilitas dan transparansi khususnya pada pihak-pihak yang berkepentingan (Stakeholder/ Shareholder/Kreditur). Analisis tata kelola perusahaan dalam beberapa tahun ini menjadi faktor kunci untuk memahami sebuah perusahaan serta sebagai salah satu indikator menculnya kepercayaan investor untuk mengambil keputusan. Bukan hanya investor, tapi juga tata kelola perusahaan digunakan manajer dan dewan direksi dalam pengambilan keputusan. Sejak tahun 1990-an, tata kelola perusahaan yang baik sebenarnya telah dijadikan patokan untuk evaluasi kepatuhan praktik bisnis dan transparansi perusahaan. Pengungkapan tata kelola perusahaan menjadi sebuah kebutuhan bagi perusahaan karena seringnya terjadi

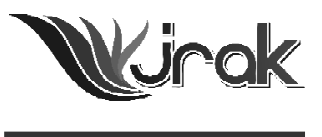

Jurnal Reviu Akuntansi dan Keuangan ISSN: 2088-0685 Vol. 6 No. 2, Oktober 2016 Pp 933-940 
Analisis

Faktor-

faktor...

934

skandal atau kesalahaan pengambilan keputusan baik oleh investor maupun manajer dikarenakan mereka tidak memahami seperti apa karakter perusahaan.

Penelitian yang dilakukan oleh Gand1a (2008) tentang Determinants of Internet-Based Corporate Governance Disclosure by Spanish Listed Companies di Valencia Spanyol mengatakan bahwa perusahaan secara umum menggunakan internet sebagai: 1) Pelaporan Keuangan; 2) Hubungan Investor; 3) Pengungkapan Tata Kelola Perusahaan. Pelaporan Kuangan menggunakan media internet merupakan bentuk transparansi dan akuntabilitas atas laporan keuangan perusahaan terhadap pihak-pihak yang berkepentingan. Dalam penelitian tersebut juga dijelaskan bahwa pengungkapan corporate governance berbasis internet mampu mengurangi asimetris informasi antara pihak manajemen dan pihak eksternal perusahaan. Beberapa alasan yang menjadi dasar corporate governance harus diungkapkan adalah: 1) Memfasilitasi komunikasi antara pihak manajemen dengan pihak-pihak yang berkepentingan (eksternal perusahaan); 2) Mengurangi biaya distribusi informasi tentang perusahaan.

McKinsey dan Company (2002) mengungkapkan bahwa tata kelola perusahaan menjadi kriteria yang signifikan dalam menentukan keputusan investasi. Investor memiliki keyakinan lebih tinggi pada perusahaan yang memiliki tata kelola perusahaan yang baik. Peraturan mengenai pengungkapan tata kelola yang diperkenalkan oleh bursa-bursa saham dan regulator seluruh dunia saat ini, mulai terlihat telah mulai menarik minat masyarakat (investor). Karena sejauh ini struktur tata kelola perusahaan beserta pengungkapannya berguna sebagai indikator untuk menilai kredibilitas informasi keuangan, menilai kualitas informasi dan juga sebagai panduan bagi para pemangku kepentingan untuk lebih yakin dalam pengambilan keputusan untuk kinerja masa depan.

Ciancanelli dan Reyes-Gonzalez (2000) dalam penelitiannya "Corporate Governance In Banking" mengungkapkan bahwa peran perbankan sangat dominan dalam aspek ekonomi suatu negara, karena peran perbankan yaitu membantu menyediakan dana pinjaman khususnya bagi pengusaha besar maupun kecil yang ingin mendirikan sebuah usaha. Dalam penelitian tersebut juga dijelaskan bahwa Corporate Governance pada perbankan lebih membahas tentang kebiasaan antara pemilik modal dan pelaksana, dimana hal itu mengacu pada Teori Agensi.

Di Indonesia, peran perbankan dalam perekonomian Indonesia lebih besar dibandingkan lembaga keuangan bukan bank (LKBB). Lembaga keuangan Bukan Bank terdiri dari koperasi simpan pinjam, biro pegadaian, dan dana pensiun. Peran Perbankan di Indonesia mencapai 87\% untuk memenuhi pendanaan khususnya perusahaan besar, sedangkan peran lembaga keuangan bukan bank hanya $13 \%$ hal itu disebabkan keterbatasan dana yang dimiliki sehingga LKBB hanya fokus kepada masyarakat kelas menengah kebawah yang kebutuhan pendanaannya tidak cukup besar.

\section{TINJAUAN PUSTAKA DAN PERUMUSAN HIPOTESIS}

Gand1a (2008) melakukan penelitian pada perusahaan yang terdaftar di Spanyol mengenai faktor-faktor penentu yang mempengaruhi pengungkapan tata kelola perusahaan berbasis internet. Hasilnya, perusahaan yang terdaftar di Spanyol belum keseluruhan dan belum secara penuh mengungkapkan variabelvariabel skor pada official websitenya.

Ponte dan Rodríguez (2002) melakukan penelitian mengenai pengungkapan sukarela menggunakan media internet pada 300 perusahaan yang terdaftar di Eropa. Hasilnya, Perusahaan di Eropa hampir secara keseluruhan mengungkapan GCG melalui internet.

Ciancanelli dan Reyes-Gonzalez (2000) dalam penelitiannya berjudul "Corporate Governance in Banking: A Conceptual Framework" mengungkapkan bahwa model corporate governance yang baik juga dipengaruhi oleh regulasi keuangan 
yang dibuat oleh pemerintah, sehingga hal itu akan berdampak pada hal apa saja yang akan diungkapkan oleh perbankan mengenai corporate governance khususnya melalui official website.

Hasil penelitian Ciancanelli dan Reyes-Gonzalez (2000) didukung dengan penelitian yang dilakukan oleh Macey dan O'hara (2003) mengenai "The Corporate Governance Of Banks" yang menyatakan bahwa untuk menyelesaikan berbagai permasalahan dalam perbankan, dibutuhkan Good Corporate yang baik, yaitu yang mampu memaparkan seperti apa struktur perbankan tersebut, bagaimana susunan direktur beserta tugas masing-masing, dan juga melaporkan seperti apa kegiatan yang telah dilakukan.

Variabel ukuran perusahaan adalah variabel yang sering diteliti dalam hubungannya dengan luas pengungkapan. Hasilnya pun cukup konsisten berpengaruh terhadap luas pengungkapan. Hikmah dan Rahmayanti (2011) menyatakan bahwa mengapa ukuran perusahaan sering menjadi variabel pengungkuran dalam pengungkapan corporate governance karena semakin besar ukuran perusahaan maka akan semakin banyak yang harus diungkapkan. Dengan demikian, maka hipotesis pertama pada penelitian ini adalah:

$\mathrm{H}_{1}$ : Ukuran Perusahaan Berpengaruh terhadap Pengungkapan Corporate Governance

Semakin lama umur perusahaan menunjukkan bahwa perusahaan tetap eksis (survive) di tengah persaingan bisnis dan situasi persaingan yang mengglobal dan berpengalaman dalam melakukan pengungkapan dari tahun ke tahun (Hikmah dan Rahmayanti, 2011). Dengan umur yang lebih lama, perusahaan diperkirakan akan meningkatkan praktik pengungkapannya karena dianggap telah memiliki lebih banyak pengalaman dalam pengungkapan laporan tahunannya dan lebih memahami kebutuhan pengguna informasi yang berkepentingan terhadap perusahaan (misalkan: Singhvi dan Desai (1971); Susanto (1992)). Chariri (2007)melakukan penelitian dengan membandingkan luas pengungkapan sukarela dalam laporan tahunan perusahaan yang terdaftar di Bursa Efek Jakarta sebelum krisis dan pada periode krisis. Salah satu variabel yang digunakan adalah umur listing. Hasil penelitian tahun 1996 menunjukkan bahwa umur listed berpengaruh terhadap luas pengungkapan berbasis media internet. Dengan demikian, hipotesis kedua dari penelitian ini adalah:

$\mathrm{H}_{2}$ : Umur Listing Perusahaan Berpengaruh Terhadap Pengungkapan Corporate Governance

Masalah corporate governance muncul sebagai akibat adanya perbedaan kepentingan antara pihak-pihak yang terlibat dalam perusahaan. Perbedaan tersebut dapat dikaitkan dengan struktur kepemilikan yang ada dalam perusahaan. Struktur kepemilikan dalam perusahaan dapat dikelompokkan menjadi struktur kepemilikan terkonsentrasi dan menyebar (dispersi). Kepemilikan terkonsentrasi adalah kepemilikan mayoritas saham oleh pihak manajerial. Kepemilikan dispersi dapat diwakili oleh persentase saham yang dimiliki pemegang saham yang kepemilikannya $\geq 5 \%$. Semakin terkonsentrasi kepemilikan saham, semakin sedikit informasi yang akan diungkapkan dalam laporan tahunan karena pihak manajemen mempunyai akses informasi yang luas tanpa harus melalui laporan tahunan perusahaan yang dipublikasikan atau manajemen sengaja menahan informasi untuk menghindari adanya pemanfaatan informasi yang diungkapkan oleh para pesaing perusahaan. Semakin menyebar kepemilikan saham, akan semakin banyak informasi yang diungkapkan dalam laporan tahunan karena adanya keinginan publik untuk memperoleh informasi seluas-luasnya mengenai perusahaan tempat ia berinvestasi dan untuk mengawasi tindakan manajemen (Hikmah dan Rahmayanti, 2011). Dengan demikian, hipotesis ketiga pada penelitian ini adalah: 


\section{Analisis Faktor- \\ faktor...}

Gambar 1

Model Penelitian Empiris
$\mathrm{H}_{3}$ : Kepemilikan Dispersi Berpengaruh terhadap Pengungkapan Corporate Governance

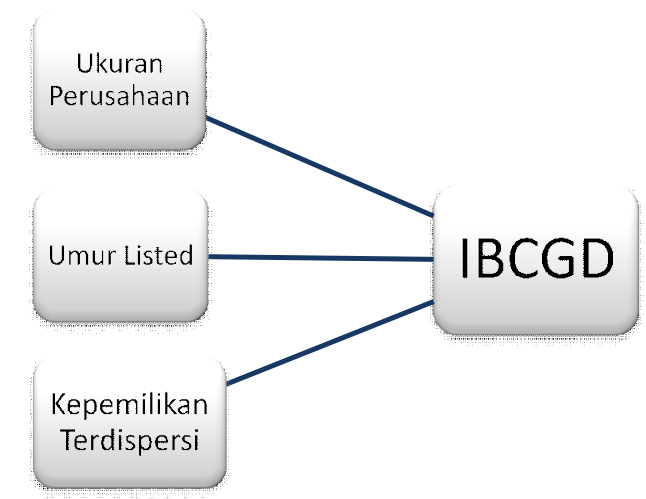

Keterangan: IBCGD=Internet Based Corporate Governance Disclosure

\section{METODE}

Penelitian ini adalah penelitian Deskriptif Asosiatif dengan mengambil objek perusahaan sektor perbankan yang terdaftar di Bursa Efek Indonesia dan termasuk dalam peringkat pengungkapan good corporate governance terbaik periode 2014-2015. Teknik pemilihan sampel menggunakan metode purposive sampling dengan kriteria: 1) Perusahaan sektor perbankan yang termasuk dalam peringkat Pengungkapan Good Corporate Governance Terbaik pada periode 20142015,2 ) Perusahaan sektor perbankan yang laporan keuangan dan Official Website bisa diakses.

Variabel Independen dalam penelitian ini adalah ukuran perusahaan, umur listed, dan kepemilikan terdispersi. Ukuran Perusahaan diukur dengan menggunakan Log Total Aset. Umur listed diukur dengan menghitung selisih antara tanggal/ bulan/tahun perusahaan terdaftar di Bursa Efek Indonesia dikurangi tanggal/ bulan/tahun dilakukannya content analysis. Kepemilikan terdispersi diukur dengan melihat berupa jumlah pihak eksternal yang presentase saham kepemilikannya $\geq 5 \%$.

Variabel dependen dalam penelitian ini adalah Internet Based Corporate Governance Disclosure (IBCGD). Internet based corporate governance disclosure adalah pengungkapan tata kelola perusahaan dengan menggunakan media internet. Untuk mengukur Internet Based Corporate Governance Disclosure dilakukan dengan content analysis yang digunakan untuk menilai 22 aspek yang diungkapkan.

Teknikanalisis data dilakukandengan: (1) Analisisisi (content analysis) dan (2) WarpPLS 3.0. PLS adalah metode penyeleseian structural equition modelling (SEM) yang dalam hal ini dapat memberikan gambaran mengenai pengaruh variabel independen terhadap variabel dependen. Pemilihan metode PLS juga didasarkan pada pertimbangan bahwa dalam penelitian ini terdapat 4 variabel laten yang dibentuk dengan indikator formative, dan bukan reflektif.

Tahapan analisis data yang dilakukan yaitu:

1. Untuk tahapan analisis isi (content analysis) adalah:

Peneliti menggunakan 4 cara sistem kode numerik (four-away numerical coding system) yang dikembangkan oleh Guthrie et al. (1999)untuk mengidentifikasi Internet Based Corporate Governance Disclosure pada Official Website perusahaan. Aspek-aspek yang diungkapkan diberi bobot sesuai dengan proyeksinya. Kode numerik yang digunakan adalah:

0: item tidak diungkapkan dalam laporan tahunan.

1: item diungkapkan dalam bentuk narasi. 
2: item diungkapkan dalam bentuk numerik.

3: item diungkapkan dengan nilai moneter.

2. Untuk tahapan analisis dengan WarpPLS adalah:

Dari Indeks yang telah diperoleh dari content analysis yang telah dilakukan, maka akan dikaitkan dengan indeks yang dihasilkan atas pengukuran variabel independen. Dari seluruh variabel, akan dapat dihasilkan 4 indeks yang nantinya akan diolah menggunakan WarpPLS. Indeks tersebut adalah IBCGD, indeks log total aset, indeks umur listed, dan indeks kepemilikan terdispersi.

\section{HASIL DAN PEMBAHASAN}

\section{Content Analysis}

Hasilidentifikasi Content analysis disajikandalamgambar2, analisisisi (content analysis) dilakukandenganmengidentifikasiaspek-aspek yang diungkapkan dalam official website perusahaan sector perbankan tentang tata kelola perusahaan. kemudian masing-masing pengungkapan diberi skor menggunakan 4 cara system kodenumerik (four-away numerical coding system).

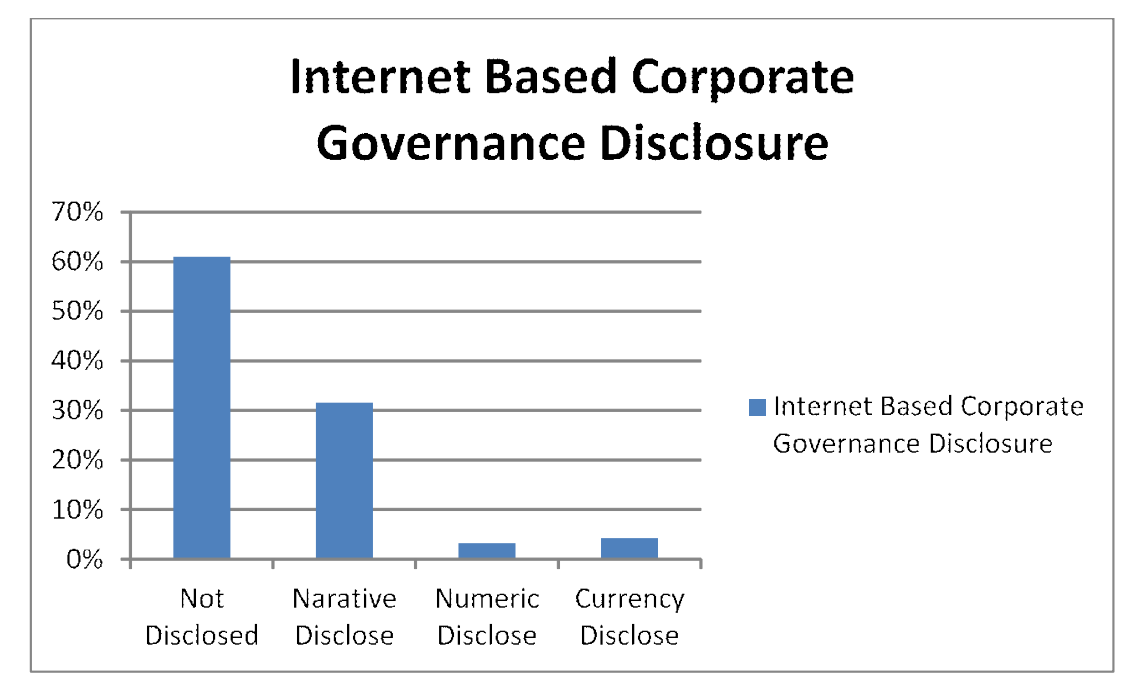

Berdasarkan Gambar 2 tersebut, menunjukan bahwa perusahaan sektor perbankan yang memiliki peringkat 30 perusahaan dengan pengungkapan Good Corporate Governance terbaik masih belum mengungkapkan tata kelola perusahaannya dengan menggunakan media internet, itu ditunjukkan dengan proporsi presentase Not Disclosure sebesar 60,91\%, hasil tersebut lebih tinggi jika dibandingkan dengan 3 skor lainnya yaitu Narrative Disclosure sebesar 31,52\%, Numeric Disclosure sebesar 3,18\%, Currency Disclosure sebesar 4,24\%. Hasil tersebut memberikan informasi bahwa perusahaan sektor perbankan dengan pengungkapan Good Corporate Governance terbaik masih belum secara efektif menggunakan media internet sebagai media akuntabilitas dan transparansi terhadap pihak eksternal khususnya. Hal itu disebabkan karena minimnya pengetahuan sumberdaya manusia yang dimiliki perusahaan mengenai penggunaan terknologi informasi khususnya internet sebagai sarana media pengungkapan.

\section{PengujianHipotesisdenganWarpPLS}

Dalam penelitian ini, pengujian hipotesis menggunakan WarpPLS diharapkan mampu menggambarkan pengaruh yang dihasilkan oleh variabel independen terhadap variabel dependen. Hasil pengujian menggunakan WarpPLS adalah sebagai berikut: 


\section{Analisis \\ Faktor- \\ faktor...}

938

Gambar 3 Hasil WarpPLS

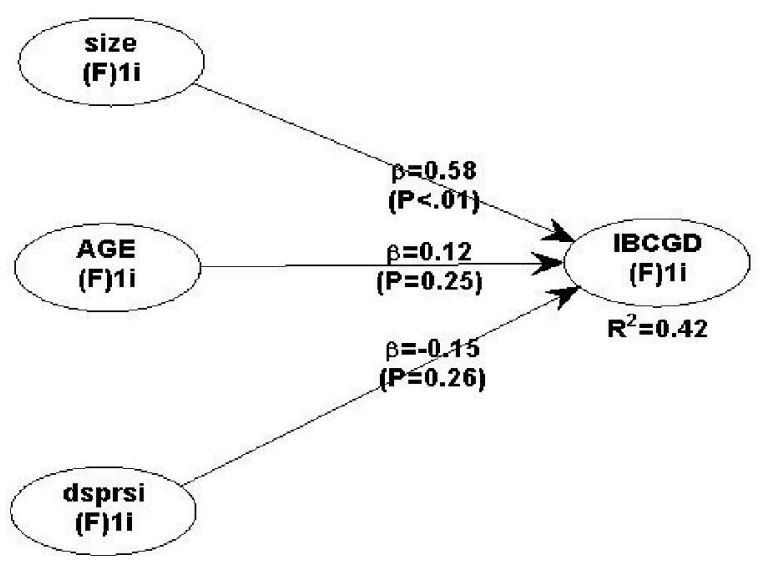

Dari gambar diatas, dapat disimpulkan bahwa ukuran perusahaan berpengaruh secara posiif terhadap Internet Based Corporate Govrnance Disclosure dengan koefisien 0,58 dan nilai p kurang dari 0,01. Salah satu yang menjadi alasan mengapa ukuran perusahaan berpengaruh terhadap internet based corporate governance disclosure adalah dalam UU No.40 Tahun 2007 Pasal 8 Tentang Perseroan Terbatas telah diatur bahwa perseroan yang mempunyai aset atau jumlah peredaran usaha dengan jumlah nilai paling sedikit Rp. 50 Milyar diwajibkan untuk di audit dan hasilnya nanti harus diungkapkan kepada publik. Sehingga semakin besar ukuran perusahaan maka semakin besar tanggungjawab yang harus dilaksanakan dan hal terebut diwujudkan dengan banyaknya aspek yang harus diungkapkan baik secara voluntary (sukarela) maupun secara mandatory (wajib diungkapkan) berdasarkan regulasi. Alasan selanjutnya adalah pengungkapan berbasis internet pastinya membutuhkan modal yang besar baik secara modal (aliran kas) maupun sumberdaya lainnya. Semakin besar aset yang dimiliki, maka perusahaan akan semakin baik dalam pengungkapan tata kelola perusahaan khususnya menggunakan media internet, karena hal tersebut didukung dengan besarnya resource yang dimiliki untuk pelaksanaan pengungkapan tata kelola berbasis internet tersebut.

Umur listed tidak berpengaruh terhadap Internet Based Corporate Governance Disclosure hal itu terlihat dari koefisien 0,12 dan nilai $p=0,25(p>0,05)$.. Salah satu yang menjadi alasan mengapa umur listed tidak berpengaruh terhadap internet based corporate governance disclosure karena seberapa lama pun perusahaan terdaftar pada Bursa Efek Indonesia (BEI) tidak akan mempengaruhi internet based corporate governance karena regulasi telah mengatur aspek-aspek yang harus dingkapkan (Mandatory Disclosure) maupun diungkapkan secara sukarela (Voluntary Disclosure).

Kepemilikan terdispersi juga tidak berpengaruh terhadap Internet Based Corporate Governance Disclosure, hal itu terlihat dari koefisien 0,15 dan nilai $\mathrm{p}=0,26$ ( $>0,05)$. Salah satu alasannya karena kepemilikan saham pada perusahaan perbankan yang terdispersi dengan tingkat kepemilikan $\geq 5 \%$ masih terkonsentrasi. Dalam hal ini, peran manajemen sebagai kepanjangan tangan dari pihak-pihak pemegang saham pengendali, sehingga pihak pemegang saham tidak menekan pihak manajemen untuk melakukan pengungkapan secara lebih luas, karena apa yang diungkapkan pada media internet akan terlebih dahulu didiskusikan pada Rapat Umum Pemegang Saham (RUPS) yang pastinya dihadiri oleh pemegang saham secara keseluruhan.

\section{SIMPULAN, KETERBATASAN, DAN SARAN}

Pengungkapan corporate governance berbasis internet pada 30 perusahaan sektor perbankan yang termasuk dalam peringkat peringkat pengungkapan good 
corporate governance dianggap masih rendah, Hal itu disebabkan karena minimnya pemahaman yang dimiliki oleh sumberdaya manusia yang dimiliki oleh perusahaan sektor perbankan tentang teknologi informasi khususnya media internet sebagai sarana pengungkapan informasi khususnya corporate governance.

Disamping itu jika dihubungkan dengan teori signal, perusahaan cenderung menunda pengungkapan informasi yang bersifat bad news guna mempertimbangkan pengaruhnya terhadap pihak berkepentingan atas informasi tersebut apabila diungkapkan.

Hasil penelitian ini membuktikan bahwa dari tiga aspek yang menjadi variabel independen dalam penelitian ini yaitu ukuran perusahaan, umur listed, dan kepemilikan terdispersi, ukuran perusahaan yang memiliki pengaruh signifikan $(p<0,01)$ terhadap Internet Based Corporate Governance Disclosure, artinya semakin besar ukuran perusahaan maka semakin banyak aspek yang harus diungkapkan guna kepentingan publik (pihak eksternal). Hal itu berhubungan dengan Pasal 68 UU No.40 Tahun 2007 yang mengatur bahwa perseroan yang mempunyai aset atau jumlah peredaran usaha dengan jumlah nilai paling sedikit Rp. 50 Milyar diwajibkan untuk di audit dan hasilnya nanti harus diungkapkan kepada publik. Sehingga semakin besar ukuran perusahaan maka semakin banyak aspek yang harus diungkapkan baik secara voluntary (sukarela) maupun secara mandatory (wajib diungkapkan) berdasarkan regulasi. Disamping itu, pengungkapan berbasis internet pastinya membutuhkan modal yang besar baik secara modal (aliran kas) maupun sumberdaya lainnya. Semakin besar aset yang dimiliki, maka perusahaan akan semakin baik dalam pengungkapan tata kelola perusahaan khususnya menggunakan media internet, karena hal tersebut didukung dengan besarnya resource yang dimiliki untuk pelaksanaan pengungkapan tata kelola berbasis internet tersebut.

Sebagaimana lazimnya penelitian empiris, hasil penelitian ini juga mengandung keterbatasan. Keterbatasan yang melekat pada pendekatan content analysis adalah potensi subjektivitas peneliti pada saat mengidentifikasi komponen komponen Internet Based Corporate Governance Disclosure dari official website. Besar peluang terjadi perbedaan persepsi di antara satu dengan yang lain pada saat menentukan apakah item tertentu diungkapkan atau tidak. Hal ini di sebabkan karena setiap peneliti memilki sudut pandang yang berbeda - beda atas 22 aspek yang diungkapkan pada official website perusahaan sektor perbankan.

Saran yang didasarkan pada keterbatasan sebagaimana telah disebutkan diatas, yaitu:Penggunaan Content Analisys untuk penelitian selanjutnya sebaiknya dilakukan lebih dari satu orang. Hal ini bertujuan untuk mengurangi subjektivitas peneliti, karena metode Content Analsis sangat rawan terhadap subjektivitas dari peneliti itu sendiri sehingga hasil yang didapatakan kurang maksimal nantinya.

\section{Daftar Pustaka}

Chariri, A. 2007. "Analisis Faktor-Faktor yang Mempengaruhi Pelaporan Keuangan melalui Internet (Internet Financial Reporting) dalam Website Perusahaan". Vol. 12, No. 6, hlm.

Ciancanelli, P., dan J. A. Reyes-Gonzalez. 2000. "Corporate governance in banking: a conceptual framework". Available at SSRN 253714, Vol., No., hlm.

Daniri, M. A. 2005. Good corporate governance: konsep dan penerapannya dalam konteks Indonesia: Ray Indonesia.

Gand1a, J. L. 2008. "Determinants of internet-based corporate governance disclosure by Spanish listed companies". eneralitat Valenciana reference GVPRE/ 2008/366, Vol. 32, No. 6, hlm: 791-817.

Guthrie, J., R. Petty, F. Ferrier, dan R. Wells. Year. "There is no accounting for intellectual capital in Australia: A review of annual reporting practices and 
Analisis

Faktor-

faktor...

940 the internal measurement of intangibles". Artikel dipresentasikan pada $O E C D$ Symposium on Measuring and Reporting of Intellectual Capital, Amsterdam, di.

Hikmah, N., dan D. Rahmayanti. 2011. "Faktor-Faktor yang Mempengaruhi Luas Pengungkapan Corporate Governance dalam Laporan Tahunan Perusahaan Perbankan yang Terdaftar Di BEI”. Simposium Nasional Akuntansi XIV, Vol., No., hlm: 1-32.

Macey, J. R., dan M. O'hara. 2003. "The corporate governance of banks". Economic Policy Review, Vol. 9, No. 1, hlm.

McKinsey, dan J. Company. 2002. Global Investor Opinion Survey: Key Findings: McKinsey \& Company.

Ponte, E. B., dan T. E. Rodríguez. 2002. "A survey on voluntary disclosure on the internet: empirical evidence from 300 European Union companies". The International Journal of Digital Accounting Research, Vol. 2, No. 3, hlm: 27-51.

Singhvi, S. S., dan H. B. Desai. 1971. "An empirical analysis of the quality of corporate financial disclosure". The Accounting Review, Vol. 46, No. 1, hlm: 129-138.

Susanto, D. 1992. "An Empirical Investigation of the Corporate Disclosure in Annual Reports of Companies Listed on the Jakarta Stock Exchange". Tim Koordinasi Pengembangan Akuntansi Jakarta. Disertasi S3, Vol., No., hlm. 